\title{
The Marian Military Reform and Its Effects on the Roman Republic
}

\author{
Siwen Cui
}

Kent School, Kent, CT 06757, USA, cuis23@kent-school.edu

\begin{abstract}
This paper investigates the impacts of Caius Marius's military reform on Roman life and politics from the late second century $\mathrm{BC}$ to the early first century $\mathrm{AD}$. It primarily consults ancient historians' biographies of prominent political figures and accounts of significant wars in the late Roman Republic, with the supplement from analysis in academic articles written by modern scholars. The thesis of this paper argues that the Marian military reform had both the direct effect of restoring strength to the Roman army and the far-reaching repercussions of facilitating violent civil wars and paving the path for the Roman government's ultimate transformation from a republic to an empire. The Marian military reform contributed significantly to the most pivotal episode in Rome's history, which became a valuable reference for political philosophers of the later generations.
\end{abstract}

Keywords: Marian reform, Roman army, Roman Republic, Roman Empire.

\section{INTRODUCTION: ECONOMIC PLIGHT, SOCIAL TURBULENCE, AND MILITARY INADEQUACY IN SECOND CENTURY BC ROME}

In the late Roman Republic, a series of fundamental military reforms pioneered by Caius Marius ultimately led to the republic's demise. The Marian military reform reorganized and restored the Roman army, escalated the use of violence and force to dictate political decisions, and left major repercussions that paved the path for Rome's ultimate transformation to a military autocracy that gave birth to the Roman Empire. The transformation was a vital turning point in Rome's history, and the reformed army played a central role in it.

What stimulated this radical change that had so great a consequence? The problem with the Roman army originated from an economic crisis in the second century BC. Since warfare overseas had become increasingly costly with Rome's rapid expansion, more and more middle-class citizens lost their property back home after their lengthy service. Additionally, a large influx of slaves from overseas conquests offered landowners free labor to operate their latifundia, with which the small farming class could not compete. These impoverished veterans were consequently reduced to the proletarian class. Due to this exacerbating economic problem that made many citizens ineligible for military service, the number of qualified citizens for conscription decreased, and the citizen militia was no longer able to preserve its strength [1]. Meanwhile, the rapid expansion of Rome's territories required more and more manpower, putting heavy pressure on the population still eligible for conscription, including the Italian allies. The promise for citizenship in return for military services had motivated the Italian allies to supplement the Roman army, but the enrollment was halted near the end of the second century. Witnessing the wealthy elites gain more riches while they earn no rewards for their sacrifices, the embittered Italian soldiers lost their main incentive to fight for Rome [2]. Thus, not only did the population available for recruitment shrank, but people also grew increasingly reluctant to serve Rome because of the overwhelming pressure and the dire consequences they had to face.

The abundance of soldiers in the Roman army was the essential factor behind Rome's dominating position, and losing the advantage posed a great threat. The efforts to ameliorate the menacing situation formally started under the Gracchi brothers. Tiberius Gracchus, the elder of the brothers, proposed a land allotment bill for the impoverished proletarians to raise them back to the property classes, hoping to qualify these men for conscription again [2]. Although Gracchus's land commission program was successfully implemented, it had a fatal flaw: veterans tended to sink back into impoverishment again. Distant campaigns still cost much time to complete, and soldiers once again faced the risk of losing their property and being reduced to the proletarian class when they abandoned their farms or businesses to serve in the army. Although Gracchus's attempt failed to remove the difficulties entirely, it was not worthless. The approach inspired Caius Marius, who proposed several military reforms that eventually cured the problem at its root and indirectly facilitated the demise of the Roman Republic. 


\section{THE REVIVAL OF THE ROMAN MILITARY}

The direct and immediate impact of the Marian reform was a reconstitution of the Roman army that made it disciplined, vigorous, and formidable to the enemies. Prior to the Marian reform, attempts had been made, but the situation was still dire. Back in $133 \mathrm{BC}$, the tribune Tiberius Gracchus proposed to reinforce the 500 iugera limit on the amount of land each individual could own, thereby allowing the government to distribute the excess ager publicus to the poor. Building upon this old law, Tiberius added 250 iugera for each son the landowner had in an attempt to raise the dwindling birth rate [2]. Tiberius once made a comment that vividly depicted the misery and the unjustness these proletarian veterans faced: "The wild beasts that roam over Italy have every one of them a cave or lair to lurk in; but the men who fight and die for Italy enjoy the common air and light, indeed, but nothing else...Though they are styled masters of the world, they have not a single clod of earth that is their own" [1]. Tiberius was determined to help this population, and with great difficulty, his land allotment bill was enacted. Unfortunately, the remedy was defective and temporary: the dearth of eligible citizens for conscription continued because the poor still lived under the oppression of the wealthy elites. After Tiberius's death, his younger brother Caius Gracchus saw the need for improvement on the existing program and undertook the arduous task in his tribunate from 123 to $122 \mathrm{BC}$. Caius ordered the government-rather than the soldiers-to cover the expense of military equipment, and the he also reinforced the age limit for military service, banning any citizen under seventeen from recruitment [3]. Caius's reform based on Tiberius's program showed that the problem with Rome's military system grew so grave that the threshold for conscription had to be lowered and that underage male citizens were forced into service to compensate for the lack of manpower. The inadequacy of the Roman army was evident in the Jugurthine War of 112 BC, in which Roman soldiers suffered multiple setbacks, but the conservative Senate continued to turn its back to the burning issue.

Although the Gracchi brothers failed to achieve the desired result, their ideas inspired Caius Marius. Marius understood the defect of the Gracchan reform, so he turned to the bane of the crisis. The first major issue with the army was its lack of motivation and loyalty. After the command of the Jugurthine War was transferred from Q. Caecilius Metellus to him, Marius decided to raise an army from the proletarians, disregarding the Senate's opposition [4]. This was a highly revolutionary but clever strategy: not only did this method of recruitment provide abundant manpower, but it also offered the wandering proletarians a serious occupation. To infuse the army with fresh energy, Marius promised to reward his soldiers with land allotment and war booty, which was exceedingly appealing to the soldiers because these riches would extricate them from poverty. In his analysis of the phenomenon, historian P. A. Brunt emphasized, "The greatest need of the poor was subsistence, and the strongest motive for the soldier was the prospect of material gain" [5]. With this revolutionary method, Marius recruited an army of motivated soldiers who were eager to obtain wealth through fighting and conquering. In addition, Marius's provision gained the army's loyalty, and to preserve their allegiance, Marius tried to win the affection and respect of his soldiers. When he was still a general under Metellus, Marius already won the goodwill of his veterans, for he did not command condescendingly and lived extravagantly while his soldiers labored on the battlefield. Instead, he "vied with the common soldiers in frugality and endurance", and through his share of their humble lifestyle, he built a close connection with his soldiers [4]. In a speech Marius delivered to the Romans, he made a sincere promise to his new and old soldiers: "I shall not treat them stingily and myself lavishly, nor win my own glory at the price of their toil" [6]. Seeing Marius's genuine wish of defending Rome, his soldiers were happy to follow him. Regarding the attitude of the soldiers, Plutarch remarked, "Every man finds solace for his labours in seeing another voluntarily share those labours; this seems to take away the element of compulsion" [4]. By these means, Marius secured the allegiance of his soldiers, and his approach proved effective in building up the army's morale and restoring its solidarity. Sallust's vivid account of a tough battle in the Jugurthine War demonstrated the restoration of the Roman army: "The Romans pressed on with greater vigour, routing the enemy...Then they rushed on over the bodies of the slain, eager for glory and each striving to be first to reach the wall" [6]. The new Marian army fought the Jugurthine War with great fortitude and courage, eventually defeating the king in $105 \mathrm{BC}$. The victory won by Marius was so swift and elegant that "the soldiers, who were kept under mild discipline and at the same time enriched, extolled him [Marius] to the skies, the Numidians feared him as if he were more than mortal" [6]. Marius gained the loyalty of the army and provided them a fresh incentive, greatly elevating their spirits.

Having obtained the loyalty and enthusiasm of his army, Marius made further attempts to train and organize his army with substantial changes. He established the cohort as the tactical unit of the army, and he ordered soldiers to carry part of their own equipment, enhancing the mobility of the army [7]. To combat the menace of the Germanic tribes on the northern border, Marius also trained his soldiers with special drills that toughened them for toil and enhanced their combat techniques. During the Cimbrian War, he stationed his soldiers at night and exposed them to the frightening sight and sound of the enemies to embolden them [4]. In another instance against the Teutones, he deliberately encamped at a site that lacked a source of water and forced his soldiers to fight for the resource at a river near the enemy's camp [4]. In addition, Marius also engaged his army in various construction projects to build their physical strength and persistence. The canal at the Rhones river, for example, was constructed by this army when Marius posed this challenge to the soldiers [4]. Most importantly, Marius 
established discipline among his soldiers. Previous armies that fought Jugurtha were characterized by "licence and debauchery consequent upon lax discipline," so much so that "whatever disgraceful excesses resulting from idleness and wantonness can be mentioned or imagined were all to be found" [6]. That the soldiers did not accept the leadership of their incapable commanders was the fundamental cause for the lack of discipline, but since Marius already gained the obedience of his army, he was able to discipline it with ease. Marius set an example with his own uprightness and supervised his army rigorously. In fact, as Plutarch commented, "his sternness in the exercise of authority and his inflexibility in the infliction of punishment appeared to them...salutary as well as just" [4]. The toughened and disciplined Roman army regained its strength, and Marius returned to Rome gloriously after suppressing the Germanic tribes. The Roman people praised him as the third founder of Rome [4]. Effectively, the Marian military reform fixed the urgent issue by restoring the Roman army's long-lost vigor and valor.

\section{THE POLARIZATION OF POWER, VIOLENCE, AND CIVIL WARS}

The influence of the Marian reform was not limited to the scope of the military: it also disturbed the republican system incidentally by placing a lot of power in the hands of individuals, leading to multiple civil wars between ambitious commanders of different factions. This new distribution of power facilitated the use of martial forces and violence to pursue personal ambitions, which, ironically, was initiated by the Optimates with the brutal murder of Tiberius Gracchus [1]. In this new recruitment system, soldiers were more loyal to the commanders who provided them provisions than to the Senate. As Sallust explained, "since he [a soldier] has no regard for his property, having none, and considers anything honourable for which he receives pay," soldiers were disposed to be grateful and obedient to their commanders who were the providers of their pay [6]. This strong attachment of an army to its leader allowed the leaders to utilize their veteran forces to achieve their personal political goals, resulting in two major civil wars that put the city and her people in great anguish.

The first civil war started between Marius and L. Cornelius Sulla in 88 BC. While Sulla held a firm belief in the traditional Republican system, Marius was a reformer. Friction between the two men originated from the Jugurthine War, and it escalated into an appalling civil war with the fight over the Mithridatic War command as its fuse. As the consul of 88 BC, Sulla received the command in Asia against Mithridates, but Marius managed to get the command transferred to himself. Much to Marius's chagrin, the army was loyal to Sulla because it followed Sulla during the Social War. In particular, the soldiers feared that Marius was going to replace them with his own choice of men and thus deprive them of the opportunity to plunder riches from the Mithridatic War [2]. Taking advantage of this, Sulla summoned the army for an unprecedented march against Rome in the excuse of "deliver[ing] her from her tyrants" [2]. Unprepared for a military confrontation, Marius and his allies fled and left the city defenseless against Sulla's force. Sulla's army was "the first army of her [Rome's] own citizens" to invade her "as a hostile country," and Sulla became the first man to seize power in Rome through pure force [2]. By these actions, Sulla set a dangerous example to his ambitious successors that escalated the use of violence in Rome.

After Sulla retired from his consulship to Asia, two new consuls were elected for $87 \mathrm{BC}$. One of the consuls, L. Cornelius Cinna, wanted to revoke Sulla's reform, whereas the other consul Cnaeus Octavius was resolute in maintaining it; therefore, violence erupted in Rome again, and Cinna was eventually defeated and expelled from the city. Seeing the importance of a strong private force, Cinna seized an army at Capua and joined forces with Marius's veteran troops [2]. Together, the two armies marched towards Rome and recaptured the city. After their victory, the soldiers performed revolting deeds and ravaged the city mercilessly. Octavius was decapitated, and his head was displayed in the forum. According to Appian's account of the event, the soldiers "killed remorselessly and severed the necks of men already dead, and they paraded these horrors before the public eye, either to inspire fear and terror, or for a monstrous spectacle" [2]. The devastation shocked and terrified the Roman people to their core; nevertheless, the atrocity in Rome was far from ending, even after Marius and Cinna both died in consulship.

In 83 BC after the Mithridatic War was finally settled, Sulla again marched towards Rome with an army of approximately 40,000 soldiers [2]. After Sulla defeated the consuls and took command, he entitled himself to supreme power as a dictator to carry out his reactionary reform. During this second invasion by Sulla, "10,000 to 20,000 men were slain in a single battle more than once," and "fifty thousand on both sides lost their lives around the city" [2]. Rome suffered heavy casualties from the bloodshed, yet Sulla was not content. He continued with his proscription and confiscation to eliminate dissent, vowing to "not spare one of his enemies, but...visit them with the utmost severity" [2]. Rome and her innocent civilians were wounded deeply multiple times by her own soldiers in the struggle for dominance between Sulla and Marius.

Another civil war flared off between Caius Julius Caesar and Cnaeus Pompeius at the beginning of 49 BC. Pompeius first rose to prominence in Roman politics as a young general under Sulla's command during the earlier civil wars [2]; therefore, he witnessed how Roman politics could be dictated by individuals with powerful armies. From the multiple campaigns he fought overseas and at home, Pompeius raised troops loyal to his command. Caesar also had a strong army that he recruited during his successful conquests in Gaul. Pompeius, Caesar, and Crassus formed the First Triumvirate, a mutually beneficial alliance in which the triumvirs each 
took what they needed. However, the triumvirate eventually collapsed in $53 \mathrm{BC}$ when Pompeius formed an alliance with $\mathrm{M}$. Porcius Cato and the Optimates. Multiple factors contributed to Pompeius's break with Caesar: the death of Crassus during the Parthian War, the death of Caesar's daughter and Pompeius's wife Julia, and Pompeius's envy and unease about Caesar's glorious exploits in the Gallic War [2]. Moreover, Cato offered Pompeius the extraordinary power he wanted by granting him the office of sole consul. In return, Pompeius sufficed Cato and the Optimates by providing a military force to combat Caesar [2]. Although Caesar appealed for a compromise repeatedly, Pompeius arrogantly rebuffed all of his proposals and insisted on an armed confrontation, believing that his army would bring a fiasco upon Caesar. In response to apprehension about Caesar's march towards Rome, Pompeius purportedly said, "In whatever part of Italy I stamp upon the ground, there will spring up armies of foot and horse" [8]. The Optimates were so determined to disgrace and subdue Caesar by defeating his army that even when the great orator Cicero attempted to bring reconciliation between Pompeius and Caesar, the Senate would not allow him [9]. The Optimates willingness to take the risk of challenging Caesar with an armed confrontation demonstrated how effective a tool violence had become for subjugating political dissent. Having no alternative, Caesar crossed the Alps and entered Italy with an infantry of 5,000 men and a cavalry of 300 men [2]. Unlike what Pompeius had promised, the Italians welcomed Caesar warmly, and when Pompeius started raising his troops, many citizens were reluctant to respond to his call [8]. In fact, Appian noted that "every soldier was strongly attached to Caesar and labored zealously for him, under the force of discipline and the influence of the gain which war usually brings to victors and which they received from Caesar also" [2]. It was the new proletarian army that consolidated Caesar's power over the Optimates. The soldiers felt personally indebted to him, and for this reason they earnestly followed him regardless of the legitimacy of his intentions. On the contrary, Pompeius overestimated the popularity of his cause. Because of his remissness, he failed to prepare fully against Caesar, and Caesar was able to force Pompeius out of Rome. Fortunately for Rome, Caesar, in contrast to Sulla, avoided bloodshed and displayed great clemency; nevertheless, Rome was again captured by her own army commanded by one of her greatest generals. Caesar himself predicted this tragedy when he hesitated by the Rubicon river and finally made the difficult decision to cross over, declaring to his soldiers that "stopping here will be the beginning of sorrows for me [him]; crossing over will be such for all mankind" [2].

The two civil wars indicated how the new proletarian veteran army divided Roman politics sharply by the lines of different political factions. Regarding this grim phenomenon, Appian wrote, "They [chiefs of factions] assailed it [their country] like a foreign enemy," performing "ruthless and indiscriminate massacres of citizens" [2]. Although revolutionary sentiment already existed far back in the second century BC, it was at this point that Rome's internal violence and commotion reached its height. Law and order gave way to force, and the fact that whoever possessed the strongest private army determined the fate of Rome fomented great unrest as prominent leaders competed for dominance. The victors often perpetrated dreadful massacres across the city to display their supremacy. In The Logic of Violence in Civil War, historian Stathis Kalyvas pointed out, "Indiscriminate violence may be used to achieve a variety of goals, such as exterminating particular groups, displacing people, plundering goods, or demonstrating a group's power and ability to hurt another group" [10.11]. Political leaders were well aware of the effectiveness of violence; thus, it became the optimum tool for advancing their causes. All of these were realized by the invention of the new proletarian army. In the late republic, Rome was mired in bitter partisan dissension and civil upheavals, which inflicted great suffering upon ordinary citizens, and the Marian military reform was certainly a contributing factor.

\section{THE TREACHEROUS PATH TO MILITARY AUTOCRACY}

Besides bringing the crucial restoration of the Roman army and the disastrous civil wars, the new proletarian army also had a profound and pivotal impact that shaped Rome's government in the following centuries: it made the centralization of power on individuals possible. At the same time, the Senate repeatedly conveyed to the Romans that it was incapable, or even reluctant, to defend the people's interests. Combined with the Senate's alienation from the civilians, the rise of private forces that entitled warlords with exclusive power paved the path for Rome's transformation from the Roman Republic to the Roman Empire.

How did the Senate lose people's confidence? The corruption within the Senate was an inveterate issue that traced down to the magistracy system. Because new commanders were elected each year for important campaigns and the nobility competed against each other fiercely for office, the armies were frequently led by inexperienced and irresponsible generals [7]. The Roman citizens and the Italian allies harbored grudges against the incompetence and negligence of the Senate for a long time, but it was not until Marius's precedent that people recognized the urgent need for them to follow competent leaders.

The ineptitude of the aristocratic leaders was manifest in the Jurgurthine War before Metellus and Marius took command. Back in Rome, nobles in the Senate were notorious for accepting Jugurtha's bribery and allowing him to escape his deserved punishments, thus prolonging the war by providing Jugurtha protection. Avarice and disloyalty were so prevalent in the Senate that Jugurtha had purportedly mocked Rome as a "city for sale and doomed to speedy destruction if it finds a purchaser" [6]. Besides bribery, the inexperience and rashness of 
commanders also posed a significant threat. The defeat of Aulus Postumius Albinus's army, for example, showed how vulnerable the Roman army became. Aulus was a presumptuous commander who temporarily took charge of his brother's army. Seeking personal glory, Aulus prepared rashly for an attack on Jugurtha and foolishly fell for Jugurtha's ruse. Jugurtha proposed a deal after he captured Aulus's army: he would release the army only if they agreed to march unarmed under a yoke. This was a blunt humiliation of the Roman army, but out of fear for death, Aulus cowardly compromised [16]. Aulus's rout disgraced the entire country, adding fuel to people's indignation and resentfulness towards the Senate's corruption. As the orator Caius Memmius said, "the senate's dignity has been prostituted to a ruthless enemy, your [the people's] sovereignty has been betrayed, your country has been offered for sale at home and abroad" [6]. From the notorious bribery and Aulus's fiasco, it was clear that Rome's value of noble heritage over true merit significantly weakened the basis of the military.

The advent of Marius, however, guided Rome to reevaluate her choices. Recognizing the ability of Marius, the people elected him for a series of successive consulships, even though this was legally prohibited. Marius was a novus homo without a strong family background, but his humble descent did not restrain people from entrusting excessive power into his hands because they were becoming progressively aware that the nobility was self-interested and unreliable. In a speech delivered to the people expressing his gratitude for their trust, Marius emphasized his distinction from and superiority over the nobles: "I can show spears, a banner, trappings and other military prizes, as well as scars on my breast. These are my portraits, these my patent of nobility, not left me by inheritance as theirs were, but won by my own innumerable efforts and perils" [6]. Marius pioneered a trend away from the traditional republican system towards military autocracy. Nevertheless, in politics Marius lacked the suaveness and undauntedness to subvert the existing authority, so he remained conservative and obeyed established law and order [4]. His more ambitious and daring successors, however, had greater schemes.

Pompeius, for example, utilized the Senate's dependence on his army to gain more power. At the age of 23, Pompeius raised an army and conferred the command on himself to fight for Sulla. Technically, Pompeius's imperium was illegitimate since he had not been qualified by the holding of any magistracy; despite this, Sulla still authorized Pompeius's command because of his outstanding performances [8]. After the civil war was settled and foreign unrest quenched, Sulla ordered Pompeius to disband his army, secretly fearing the growing power of this young general. Not only did Pompeius bluntly refuse Sulla's order, but he also made a shocking request by demanding a triumph. Sulla instantly rejected Pompeius's demand because he was simply unqualified for a triumph: his imperium was entitled to him by Sulla as a dictator and was thus not truly official. Not accepting this, Pompeius threatened to employ his private force if Sulla insisted on thwarting his plan. Shocked by Pompeius's boldness and fearing another insurrection that would disrupt the agenda of his reactionary reform, Sulla had to compromise [8]. The ability of an officer with a strong private force to command the government to fulfill his personal desire ironically betrayed Sulla's principle that emphasized the restoration of power to the Senate. Even after Sulla enacted laws that returned power lost in the Gracchan and Marian reforms to the Senate, the Senate was still in no position to curb the growing power of warlords. The situation only grew more extreme after Sulla's retirement and the repeal of nearly all of his policies. When Pompeius returned with victory from the confrontation with M. Aemilius Lepidus, he continued to find excuses for not demobilizing his army, and again the Senate complied with him. Thus, Pompeius kept his army until the Senate dispatched him to aid Q. Caecilius Metellus Pius in Spain against Quintus Sertorius [8]. Similarly, when Pompeius finished his campaigns against Sertorius and the slave rebellion at home, he required a second triumph, which was another excuse for keeping his army. Pompeius was also permitted to stand for the consulship in $71 \mathrm{BC}$, even though he was way under the age limit and had not ascended to consulship through the cursus honorum [8]. The Senate conceded to Pompeius multiple times, allowing him to retain his imperium. In the following years, the Senate offered an incredible amount of power to Pompeius by entrusting him with various tasks of subduing foreign upheavals and fixing domestic problems. From these instances, it was apparent that the Senate had become increasingly dependent on Pompeius's leadership and, at the same time, intimidated by the strength of his army. This was particularly the case when Cato and the Optimates sacrificed some of their conservative commitment to reach an alliance with Pompeius against Caesar. Cato, a strict Optimate, even agreed to appoint Pompeius as sole consul in $52 \mathrm{BC}$, granting Pompeius essentially dictatorial power. Through a sole consulship, Pompeius enjoyed exclusive control over two major provinces, the public money, and his army to curb the chaos in Rome and the hostility abroad [2]. This dependence on Pompeius exposed the Senate's incapability of safeguarding themselves in a military confrontation. People learned that Roman generals with a loyal army were the rulers and protectors of Rome in effect. Historian Erich Gruen suggested, "When the nobility ultimately came to terms with him, under the pressure of necessity, it dramatized beyond repair its own discredit" [12]. As Gruen pointed out, the Optimates' compromise with Pompeius was essentially suicidal, as it damaged its own principles. At the same time, Pompeius's impressive military achievements brought him considerable popular support, and he solidified it with attempts to restore the authority of the tribunes [8]. Taking advantage of this weakness of the Senate, Pompeius collected much power into his own hands.

Although Pompeius did not completely subvert the Senate because he pursued his own honor rather than an 
overthrow of the oligarchy, his contemporary Caesar managed to take a further step. In the early stages of his political career, Caesar won the affection of the people by highlighting his familial bond with Marius and Cinna and conveying that he stood for the populace [9]. People saw in him a charismatic leader of eloquence, generosity, valor, and commitment to defending their interests. Caesar's devotion was in stark contrast to the apathy of the Senate, which only concerned the nobility and neglected the needs of the common people. In his Commentaries on the Civil War, Caesar stated that "the interest of the commonwealth had always been dearer to him than life; but he could not help grieving at the malice of his enemies, who had frustrated the good intentions of the Roman people in his favour" [13]. Caesar was well aware of people's complaints towards the Senate's damage to their interests, so he utilized this sentiment to further alienate the Senate from the people and gather more popular support for himself. Through the tragic death of Pompeius, the Romans saw that their existing government was so weak that it failed to defend even its own cause, and all its schemes only inflicted more suffering on the city. Eventually, they handed Caesar a perpetual dictatorship, "regarding the monarchy as a respite from the evils of the civil wars" [9]. Even though the people understood that the perpetuity was not only a complete shatter of the Roman laws but also a dangerous fuse to tyranny, they resorted to this because they had no faith left in the Republican system. Whether they regretted their decision or not, it was obvious that the Senate had become so odious, short-sighted, and impotent that its progressive alienation from the people culminated in the republic's burial by her own people. Even after his popularity dwindled because of the excessive honors bestowed upon him, Caesar still had a loyal group of followers that vowed revenge for him on his assassins [9]. Historian Arthur F. Stocker commented, “...The 'Republic' was dead, and few there were to mourn it, except for the privileged little group of senators who had constituted the ruling oligarchy. For the 'Republic' had long ceased to be anything but an oligarchy, ruled with shameless self-seeking by a small circle of selfstyled nobles" [14]. Indeed, Caesar's perpetual dictatorship marked the official end of the republic, but many Romans deemed it necessary because the Senate was so incompetent. It was the Senate's alienation from the people and the advent of the Marian proletarian army that created the perfect political environment for Caesar, who already possessed great magnetism and distinction, to build his prominence. Although Caesar was assassinated before he carried out all of his plans, one of his followers, Caius Octavius, who was also Caesar's chosen heir, completed his great scheme and constructed the Augustan Principate.

After defeating his opponent Marcus Antonius, Octavius became the leader of Rome. On the surface, he intended to restore peace in Rome, but the essential changes in Roman politics were irreversible, for with power centralized in the hands of one man, the country could not return to its republican system. Regarding the dictatorial power after Caesar's reign, Historian Victor Ehrenberg argued, "Legality and temporariness had gone, and with them most of the substance of what was characteristically Roman. Nothing remained but the fact that the imperium was extraordinary" [15]. At this point, the nominal republic remained as an empty shell, and on the inside it had decayed almost completely. During his long reign that extended from $31 \mathrm{BC}$ to $14 \mathrm{AD}$, Octavius reconstructed the empire following Caesar's ideology. In $22 \mathrm{BC}$, Octavius rejected the dictatorship that the Senate offered to him [16], perhaps sensing the dangerous implication of this title; nevertheless, the tremendous power entitled to him by the various offices he held covered not only military but also religion and finance, making Octavius virtually a dictator. Most importantly, Octavius used his patrimony and the spoils of his overseas conquests to distribute massive amounts of money to the Romans and to reward his soldiers [16]. In addition, all civilians and soldiers of Italy swore their allegiance to Octavius [16]. The fact that Octavius was the man whose brilliant leadership everyone depended on when crisis arose tied all Italians strongly to him, and therefore simultaneously, it facilitated the development of an empire that replaced the republic. The Augustan principate was the embryo of the Roman Empire, and it started a new chapter in Rome's history.

Although Marius himself might not have intended to do so, the new type of army that Marius created had great political repercussions that ultimately facilitated the collapse of the republican system and the construction of a new empire. The downfall of the Roman Republic was certain as long as it continued to ignore the necessity for changes, but without the new Marian army, leaders might not be able to centralize power so quickly; therefore, the new Marian army was a central component of Rome's transformation. Marius's leadership was the precursor of the later dictatorships, and the progression from Pompeius to Caesar to Octavius gradually eroded the republican system and replaced it with a military autocracy. The causality was quite subtle, and it took more than eighty years for this profound impact to fully reveal itself; however, the new Marian army certainly played a crucial role in the eventual demise of the Roman Republic.

\section{CONCLUSION: THE PROFOUND LEGACY OF THE MARIAN REFORM}

Building upon the previous efforts of the Gracchi brothers, the military reform of Caius Marius created a professional army that defended Rome against its foreign enemies, prompted political factions to achieve their partisan objectives through violence and civil wars, and paved the path for Rome's ultimate transformation into an empire led by military autocracy. The immediate effect of the army's restoration was evident in the magnificent victories against Jugurtha and the Cimbri and Teutones, whereas the more profound repercussions were felt in the cruelty of the civil wars and the final downfall of the Roman Republic decades after Marius 
enacted his reform. Both the immediate effects and the profound repercussions, however, were important turning points in Rome's history. These impacts were relevant and important not only to the ancient Romans but also to modern scholars, as they left valuable historical legacies that constructed the foundations of modern politics. The new Marian army brought brilliant leaders like Pompeius, Caesar, and Octavius to prominence in the world of the Romans, and people today continue to admire these great figures and their marvelous legends. The Marian military reform was an important episode in the evolution and advancement of primitive human civilization to the modern political environment that we live in. Even after the Byzantine Empire fell to the Ottomans in 1453, which was more than a millennium after the end of the Roman Republic, the political philosophy of Rome survived and remained a valuable reference to many thinkers and politicians in later generations.

\section{REFERENCES}

1. Plutarch. Tiberius Gracchus. Translated by Bernadotte Perrin. http://www.perseus.tufts.edu/hopper/text?doc=Pers eus:text:2008.01.0065.

2. Appian. The Civil Wars. Translated by Horace White.

http://www.perseus.tufts.edu/hopper/text?doc=Pers eus:text:1999.01.0232.

3. Plutarch. Caius Gracchus. Translated by Bernadotte Perrin.

http://www.perseus.tufts.edu/hopper/text?doc=urn: cts:greekLit:tlg0007.tlg052b.perseus-eng1:1.

4. Plutarch. Caius Marius. Translated by Bernadotte Perrin.

http://www.perseus.tufts.edu/hopper/text?doc=urn: cts:greekLit:tlg0007.tlg031.perseus-eng1:28

5. Brunt, P. A. (1962) "The Army and the Land in the Roman Revolution." The Journal of Roman Studies 52: 69-86. https://doi.org/10.2307/297878.

6. Sallust. (2015) "The Jugurthine War." In: John, C.R. (Eds.), The Jugurthine War and The Conspiracy of Catiline. ROMAN ROADS MEDIA. Moscow. pp. 1-89.

7. Billows, Richard A. (2012) Julius Caesar: The Colossus of Rome. Routledge Classics. London.

8. Plutarch. Pompey. Translated by Bernadotte Perrin. http://www.perseus.tufts.edu/hopper/text?doc=urn: cts:greekLit:tlg0007.tlg045.perseus-eng1:1.1.

9. Plutarch. Caesar. Translated by Bernadotte Perrin. http://www.perseus.tufts.edu/hopper/text?doc=urn: cts:greekLit:tlg0007.tlg048.perseus-eng1:1.

10. Kalyvas, S.N. (2006) "The Incidence of Indiscriminate Violence." In: The Logic of Violence in Civil War. Cambridge University Press, Cambridge. Pp.146-148.

11. Lange, C.H. (2014) "The Logic of Violence in Roman Civil War." Hermathena, no. 196/197: 6998. https://www.jstor.org/stable/26740130.
12. Gruen, E.S. (1969) "Pompey, the Roman Aristocracy, and the Conference of Luca." Historia: Zeitschrift Für Alte Geschichte 18, no. 1: 71-108. https://www.jstor.org/stable/4435061.

13. Julius Caesar. Commentaries on the Civil War. Translated by William Duncan. http://www.perseus.tufts.edu/hopper/text?doc=urn: cts:latinLit:phi0448.phi002.perseus-eng1:1.0.

14. Stocker, A.F. (1970) "Julius Caesar as a Political Leader." The Classical Outlook 48, no. 2: 18-20. https://www.jstor.org/stable/43931181.

15. Ehrenberg, V. (1953) "Imperium Maius in the Roman Republic." The American Journal of Philology 74, no. 2: 113-36. https://doi.org/10.2307/292492.

16. Augustus. The Deeds of the Divine Augustus. Translated by Thomas Bushnell. http://classics.mit.edu/Augustus/deeds.html. 